\title{
Study on the Characteristics of Electronically Commutated Motor
}

\author{
B. Karaliunas \\ Department of Automation, Vilnius Gediminas Technical University, \\ Naugarduko str.41,LT-03227Vilnius, Lithuania, phone: +370 27450 63, e-mail: bronius.karaliunas@el.vgtu.lt
}

\section{Introduction}

Generally, DC motors in which the units of brushes and collectors are missing and the current in the windings is commuted by an electronic device are conventionally called electronically commutated motors. In scientific publications they are available as EC motors, electronic motors, brushless motors or commutatorless motors [1].

Lately, the field of application of EC motors has grown considerably. They distinguish themselves by good weight and size relation in connection to power, they exhibit perfect characteristics concerning starting and control and they generate less acoustic and electric noise if compared to collector type motors. In collector type motors, the brushes monitor commutation by mechanically switching the sections of windings within the required time. In EC motors the commutation of currents is electronically controlled. The information for the electronic device to start commutation could be supplied by means of position sensors or the signal of phase electromotive force generated in the windings. Position sensors are mostly applied in cases when high torque starting is required and when that torque is frequently variable. The same type of sensors is used in motors intended for positioning. The control of EC motors without sensors is generally provided when the initial torque is constant and when the monitoring of the rotor position is not important [2].

EC motors are applied in robots, air - conditioners, vacuum cleaners, ventilators, printers, coffeemakers, electric bicycles, razors, disk drives. Due to sufficient relation of power to mass and because of a reliable mode of control these motors are widely installed in the designs operated by radio waves and in some other cases as well. They could be applied in air conditioning installations for buildings, where they exhibit high coefficient of efficiency and low level of noise making [3]. Moreover, there have recently appeared the scientific studies analysing the characteristics of such motors and describing the systems of their control $[3,4]$. For the control of EC motors there are well acknowledged the systems where the commands are presented in digital or impulsive form. Owing to that phenomenon in the control systems of EC motors there are installed the units accepting, processing and transmitting digital signals.

Despite the fact, that the static characteristics of EC motors are analysed rather extensively, but the dynamic characteristics for various modes concerning their running and control haven't been thoroughly investigated yet.

The objective of the work is to compile the digital model of the dynamic processes for the EC motor and obtain the simulation results of their dynamic characteristics.

\section{Commutation of currents for EC motor and calculation of the torque}

The performance of EC motors is based on the rotational magnetic field. To generate this type of field in the stator of the motor there have to be present at least three phase windings, which are connected in between by a star or triangle. The electronic switchboard supplies in turns the voltage into the windings of the stator within the required moment. The rotor has the installed permanent magnets, which generate the magnetic flux of the rotor and rotate towards the direction of the magnetic field of the stator.

In EC motors the commutation of currents in the windings of the stator could be rectangular, sinusoidal or there could be commutation without sensors. To obtain the currents of the required direction in the windings of the stator, it is necessary to have information regarding the angular position of the rotor. The following items are able to satisfy the required conditions, namely Hall sensors, the signals of optic encoders or by monitoring the moment when the electromotive force of the phase passes the zero.

In order to calculate the torque of the motor, the rectangular impulse of the current could be split into two components: direct and alternative. In the received results of the calculations it is sufficient to evaluate only the first spatial harmonic of the variable component. Then the longitudinal density of the stator current could be expressed in the following way [5]

$$
A_{1}\left(x_{1}\right)=A_{1 m} \sin p x_{1}
$$


where $A_{1 m}$ - is the amplitude of the longitudinal density of the current; $p$ - is the number of pairs poles; $x_{1}-$ is the spatial coordinate of the stator winding.

The density of the magnetic flux of the rotor in the air gap is equal to

$$
B_{2}\left(x_{2}\right)=B_{2 m} \cos p x_{2}
$$

where $B_{2 m}$ - is the amplitude of the density of the magnetic flux; $x_{2}-$ is the spatial coordinate of the rotor.

In (1) and (2) expressions, the coordinates $x_{1}$ and $x_{2}$ are the parameters of the arc of the stator and rotor. When the rotor is turned in angle $\varphi$, there exists the relationship between these parameters

$$
x_{2}=x_{1}-\varphi
$$

To calculate the rotational torque of the motor there is generally applied the following expression

$$
M=l r^{2} \int_{0}^{2 \pi} A_{1}\left(x_{1}, t\right) B_{2}\left(x_{1}, t\right) \mathrm{d} x_{1}
$$

where $l$ and $r$ - are the length and the radius of the package of the rotor.
The longitudinal density of the current as well as the density of the magnetic flux of the rotor does not disagree within the time. If expression (4) try to solve together with expressions (1), (2), (3) we could get the following

$$
M=\frac{\pi l r^{2} A_{1 m} B_{2 m}}{2} \sin p \varphi .
$$

The obtained result indicates that the rotational torque of the motor is the angular function of the turn of the rotor.

\section{Digital model compiling for EC motor}

To investigate the characteristics of the motor there is applied the digital model (Fig. 1) compiled by means of Matlab/Simulink software package. In Fig. 1 the structure of the model corresponds to the unit „mybldc“, the signals of voltage of the power supply serve the inlets, the outlets are the parameters of the motor. The central controller is installed in the unit of ESTIMATE. It determines the difference between the present and the set velocities and if PID regulator is installed, it determines the desired commutation moment of the currents.

To obtain the results of simulation the following initial data are introduced into the Matlab/Simulink model:

- $\quad$ Supply voltage $U=48 \mathrm{~V}$;

- $\quad$ Armature circuit resistance $R_{f}=4,4 \Omega$;

- Maximum velocity $n_{\max }=12000 \mathrm{r} / \mathrm{min}$;

- Current of starting $I_{k}=10,9 \mathrm{~A}$;

- Rotor inertia torque $J_{r}=101 \mathrm{gcm}^{2}$;

- Electromechanical constant of time $T_{m}=4,81 \mathrm{~ms}$.

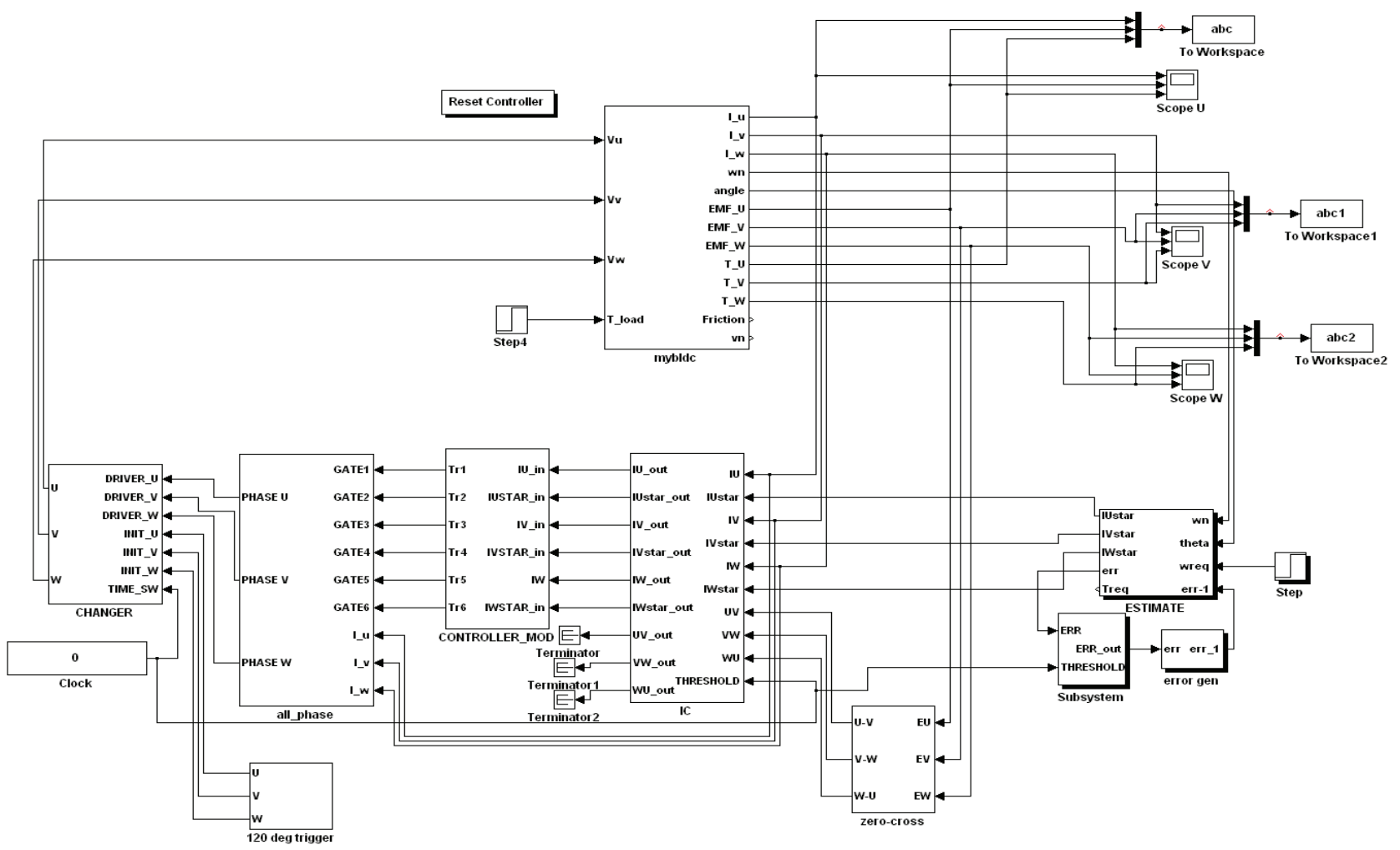

Fig. 1. Matlab/Simulink model for three phase EC motor 


\section{The results of the digital model simulation}

Due to the fact, that phase electromotive force is proportional to the velocity of the rotation of the rotor, and then in cases of low velocities the signal of the electromotive force could be week enough to accurately determine the point of the zero ordinate. Therefore, there were investigated the characteristics of the motor under various velocities of the rotor.

Fig. 2 presents the diagrams of the phase electromotive forces, at the moment of starting the motor till reaching the determined velocity $\omega=100 \mathrm{rad} / \mathrm{s}$.

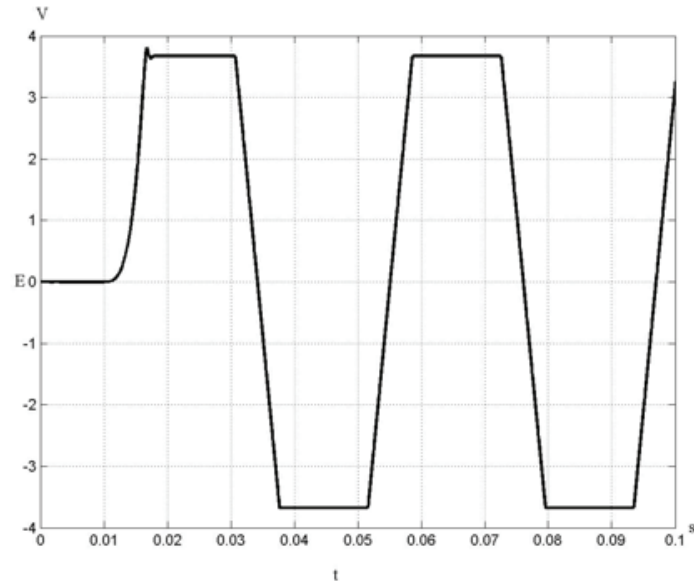

a)

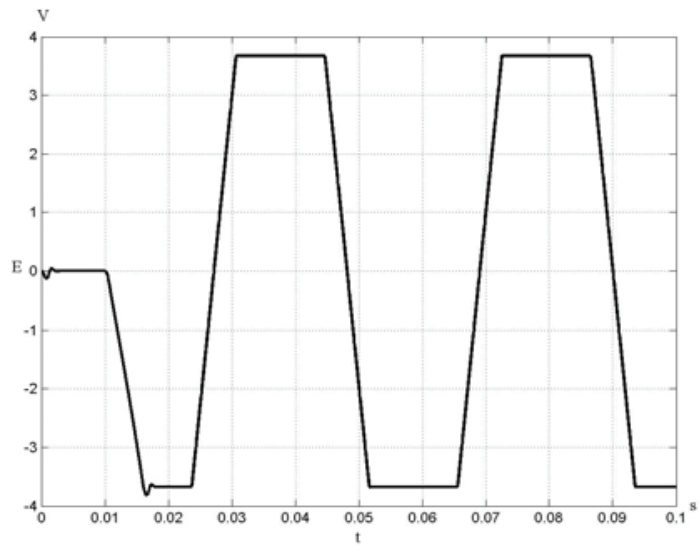

b)

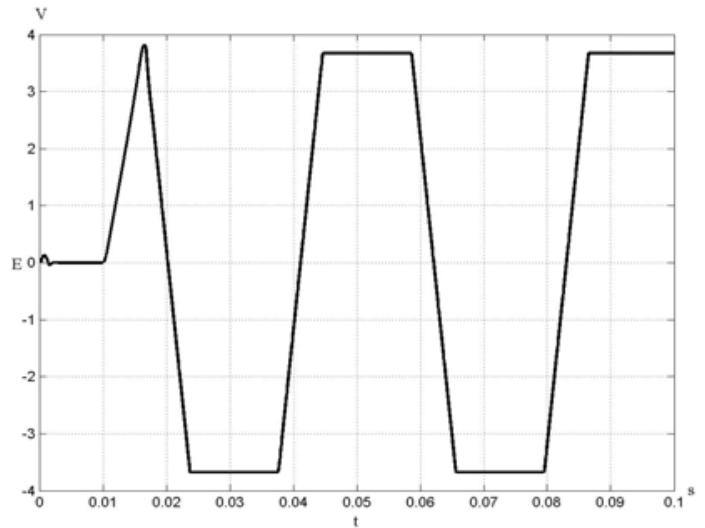

c)

Fig. 2. The diagrams of the phase electromotive forces: a) - of phase $\mathrm{U} ; \mathrm{b}$ ) - of phase $\mathrm{V}$; c) - of phase $\mathrm{W}$
Fig. 3 presents the diagrams for the current and torque variations, when the power is supplied to $U$ phase and the velocity of the rotor is $\omega=100 \mathrm{rad} / \mathrm{s}$. The analogue diagrams are also received in cases when the power is supplied to $\mathrm{V}$ and $\mathrm{W}$ phases.

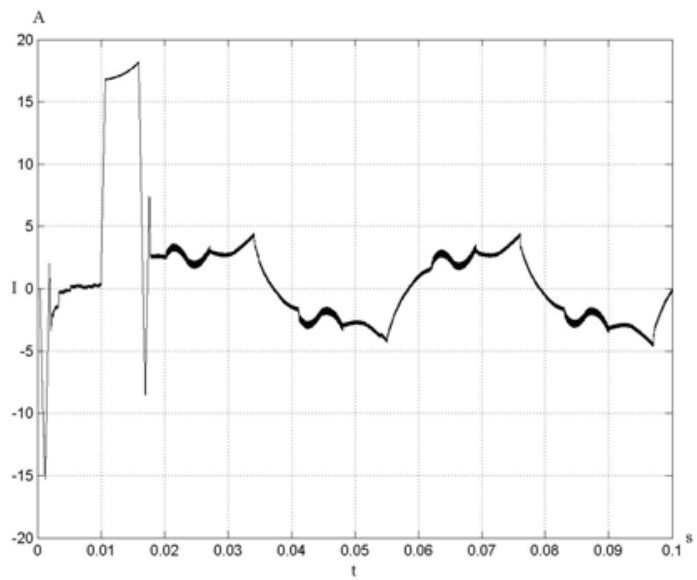

a)

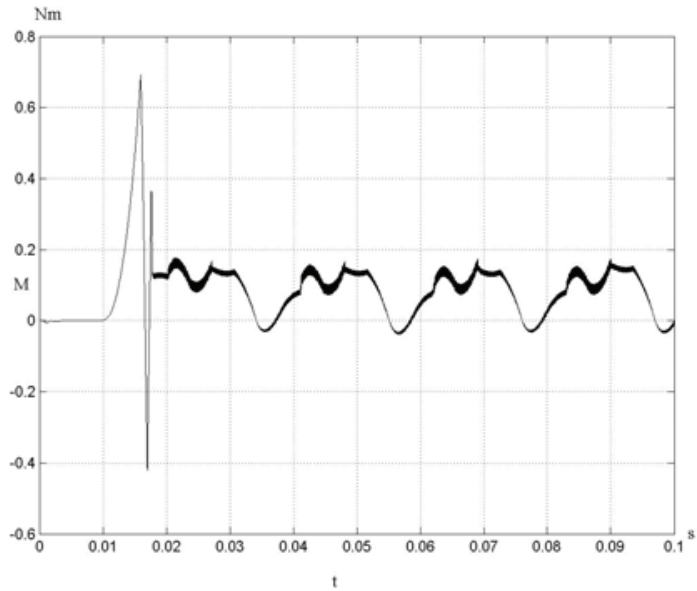

b)

Fig. 3. Diagrams of variations for: a) - current; $b$ ) - torque, when the power is supplied to $U$ phase, rotor velocity is $\omega=100 \mathrm{rad} / \mathrm{s}$

Fig. 4 presents the diagrams for the current and torque variations when the power is supplied to $U$ phase and the velocity of the rotor is $\omega=300 \mathrm{rad} / \mathrm{s}$.

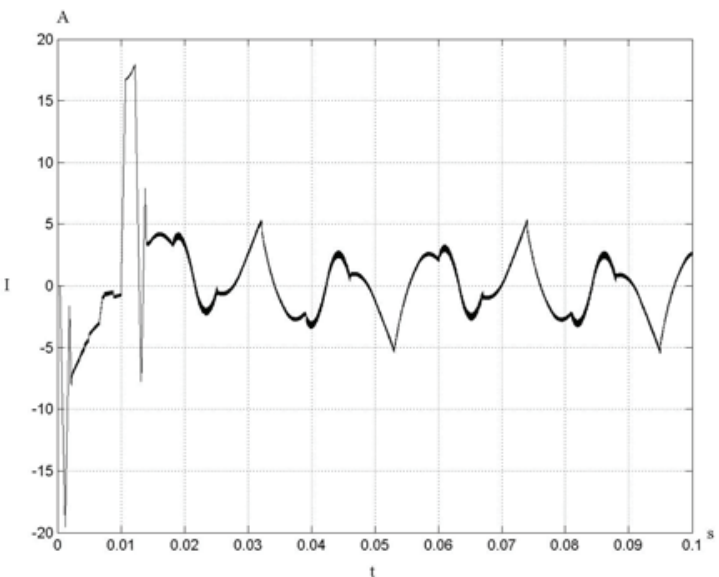

a) 


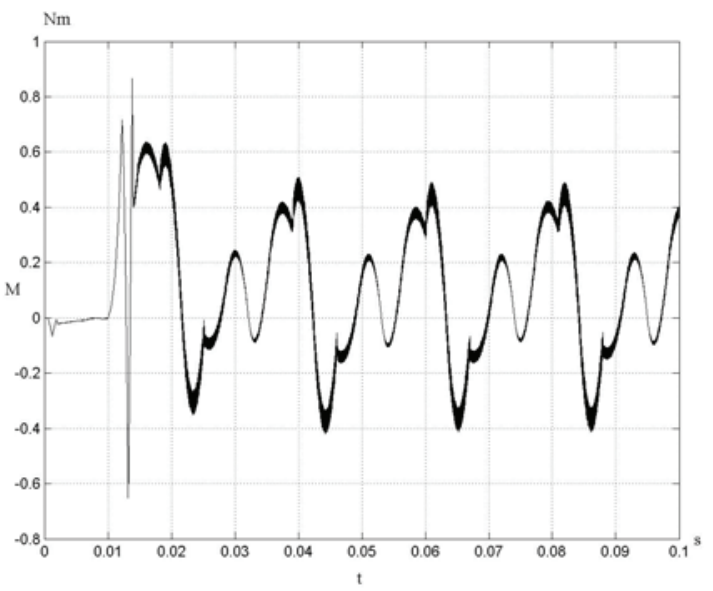

b)

Fig. 4. Diagrams of variations for: a) - the current; b) - the torque, when the power is supplied to $\mathrm{U}$ phase

\section{Conclusions}

1. The presented digital model Matlab/Simulink compiled for EC DC motors enables to investigate the dynamic characteristics under various parameters of the motor and by determining the dimensional position of the rotor in accordance with the point of intersection of the zero for the phase electromotive force.

2. The results of the research indicate that the efficiency of the commutated motor depends on the accuracy of the commutation moment of the stator windings.
The moment could be determined by measuring the electromotive force of the phase or by means of the signals of Hall sensors.

3. Although the control of EC motors without sensors reduces the price of the drives, but such a mode causes problems for the starting of the motor as well as it turns not to be precise. Therefore, in most cases for the information on the angular position of the rotor to be received there are applied Hall sensors with permanent magnets.

4. When optimizing the EC motor performance, for the optimization criteria could be selected the lowest current of the motor under the adequate velocity of the rotor rotation and the task could be solved by optimization search methods.

\section{References}

1. Smilgevičius A. Micro machines of automation. Automatikos mikromašinos. Vilnius: Technika, 2005. - $344 \mathrm{p}$.

2. Moreton P. Industrial Brushless Servomotors, a Practical Handbook. - Newnes, 2000. - 191 p.

3. Karaliūnas B. Optimization of Two-Mass Electromechanical System // Electronics and Electrical Engineering. - Kaunas: Technologija, 2010. - No. 7(103). - P. 43-46.

4. Karaliūnas B., Matkevičius E., Radzevičius L. Magnetic Field in the Air Gap of Double - Sided Linear Induction Machine // Electronics and Electrical Engineering. - Kaunas: Technologija, 2008. - No. 5(85). - P. 13-16.

5. Karaliūnas B., Matkevičius E., Radzevičius L. Peculiarities of the Linear Induction Machine, Operating at the Mode of Phase Regulator // Electronics and Electrical Engineering. Kaunas: Technologija, 2009. - No. 4(92). - P. 83-86.

Received 20101215

B. Karaliunas. Study on the Characteristics of Electronically Commutated Motor // Electronics and Electrical Engineering. Kaunas: Technologija, 2011. - No. 3(109). - P. 31-34.

The article presents the study on the electrically commutated DC motors or on the so called studies of the fields of application of brushless motors, considering their advantages and disadvantages. The computerized simulation model Matlab/Simulink of the characteristics of the EC motor was compiled, their units of operation were described as well as the methodology of their simulation. There are presented the curves of the change of the electromotive force induced in the phase winding of the motor, the cur rents and the moments of the motor under the various velocities of the rotor rotation. The obtained results indicate that the efficiency of the commutated motor depends on the accuracy of the commutation moment of the stator windings. Ill. 4, bibl. 5 (in English; abstracts in English and Lithuanian)

B. Karaliūnas. Elektroniškai komutuojamo variklio charakteristikų tyrimas // Elektronika ir elektrotechnika. - Kaunas: Technologija, 2011. - Nr. 3(109). - P. 31-34.

Nagrinejjamos elektroniškai komutuojamų nuolatinės srovės variklių, kitaip dar vadinamų bešepečių variklių, taikymo sritys, jų teigiamybės ir trūkumai. Sudarytas EC variklio charakteristikų tyrimo kompiuterinis modelis programų paketu Matlab/Simulink, aprašyti jo veikimo blokai ir modeliavimo metodika. Pateiktos variklio fazinèje apvijoje indukuotu elektrovaru, srovių ir variklio momento kitimo kreivès, esant skirtingiems rotoriaus sukimosi greičiams. Gauti rezultatai rodo, kad elektroniškai komutuojamo variklio efektyvumas priklauso nuo statoriaus apvijų komutavimo momento tikslumo. Il. 4, bibl. 5 (anglų kalba; santraukos anglų ir lietuvių k.). 